\title{
The Curriculum Reform and Practice of SCM against the Backdrop of Engineering Certification
}

\author{
Liu Yuan, Wu Haiyun, Wei Yong* \\ College of Engineering and Technology \\ Tianjin Agricultural University \\ Tianjin, China \\ 1417325528@qq.com
}

\begin{abstract}
According to the engineering education professional certification standards, the research found that measurement $\&$ control courses are less relative to the training objectives of engineering majors, and the support for graduation requirements is relatively low, no matter the formulation of curriculum syllabus, the selection of teaching mode and the design of teaching circumstance, which are directly related to the quality of professional talents culture. In view of these problems, this paper takes the SCM as an example to reform and explore from the curriculum syllabus, teaching mode and assessment mode. The practice has proved that the reform measures have promoted the students' interests in learning and improved the effect of the curriculum teaching.
\end{abstract}

Keywords-Engineering education certification; SCM; Curriculum reform; Graduation requirements

\section{ENGINEERING EDUCATION PROFESSIONAL CERTIFICATION}

The professional accreditation of engineering education is an internationally accepted quality assurance system for engineering education. It is also an important basis for international mutual recognition of engineering education and international recognition of engineer qualification. "Washington Accord" is the most influential agreement on mutual recognition for the international undergraduate engineering degree in the world. It is a kind of qualified evaluation, training target and graduation requirements orientated. China is a member of this agreement, its purpose is through bilateral or multilateral recognition of engineering education and qualification engineer qualification engineer, promote international practice, and construct quality monitoring system of Engineering Education in China, to promote the engineering education reform in our country and improve the quality of engineering education; As well as to help to build up contact mechanism between engineering education and business circles, enhance the adaptability to the industrial development of the talent training of Engineering education [1]. In the professional certification of engineering education, the training objectives, the requirements of graduation and the curriculum system are the three core elements of the training program. Curriculum, course content, course teaching and curriculum evaluation should be able to fully support the completion of graduation requirements, directly related to the quality of professional training in this paper, a series of reforms and explorations are carried out with the principle and application of single chip (SCM) as the medium, and the certification of engineering education as the standard.

\section{THE PROBLEMS IN COURSE TEACHING}

\section{A. The formulation of the syllabus does not reflect the relationship between the various elements and the achievement level of graduation requirements}

The syllabus is a document of the teaching content of a certain course according to the teaching plan. The traditional syllabus includes the teaching purpose, task, knowledge scope and the allocation of teaching hours. It does not reflect the relationship between the various elements and the achievement level of graduation requirements, and fail to reflect the degree of professional standards in the learning links of the learners.

\section{B. The flexibility of teaching methods is not enough}

The traditional teacher centered teaching method and the single teaching method cannot meet the requirements of teaching students in accordance with their aptitude. How to stimulate students' interest and make them learn actively is the problem to be solved by teachers.

\section{The evaluation of the implementation effect of various teaching links is lack of scientific nature}

To reflect students' knowledge level, it usually uses homework evaluation, writing test reports and examinations. However, practice has proved that this teaching evaluation method often fails to reflect students' knowledge level and the problem of lack of training.

\section{Neglecting students' non-professional technical factors}

The modern engineer is a social person with social responsibility. The students are restricted by various factors such as economy, environment, law, ethics, etc. during engineering design. Whether students with engineering consciousness, team spirit and comprehensive ability to use knowledge to solve practical problems of the complex is particularly important. However, it is often not enough on cultivating students' non- professional technical factors in the course of teaching, it also ignores the examination and evaluation of non- technical factor. 
In order to solve the problems in the course teaching, we take a series of explorations with the example of SCM course.

\section{THE METHODS AND MEASURES OF CURRICULUM REFORM}

\section{A. The goal of the SCM course}

SCM is the basic course of measurement and control specialty and also one of the important courses of measurement and control specialty. Taking the knowledge of hardware structure, programming method and interface technology as the core, combined with typical application examples, it expounds the development process of SCM system, hardware composition and connection, software design and system debugging. The combination of hardware and software is one of the features of this course.

SCM aims at training students' engineering practice ability, enabling students to acquire basic knowledge and skills of SCM, and have the ability of applying SCM for equipment transformation and product development.

\section{B. Formulation curriculum syllabus in conformity with the professional accreditation of engineering education}

To ensure the effective achievement of training objectives, theses contents should be written in the course of teaching large classes, in which including engineering education certification requirements, embodying the cultivation of students' knowledge, ability and quality in teaching, the expected effect on students learning of this course, the course of graduation requirements for support.

Before the syllabus was formulated, the teaching objectives and curriculum contents were discussed and studied in terms of the 12 graduation requirements of engineering education accreditation, taking the course group as a unit. And the programming ideas and project elements for curriculum syllabus were formed [2]. The syllabus should include: course introduction, expected learning results, pre- training requirements, teaching materials and other teaching resources, main teaching links, curriculum assessment, learning progress, experiment and practice.

1) The support of the curriculum to the requirements of graduation

The syllabus clearly points out the expected learning results supported by teaching contents. It not only embodies the knowledge acquisition and professional ability training, but also integrates the training of non- professional qualities, and reflects support of the curriculum to the requirements of graduation, as shown in Table I.

In Table I, the weight is the proportion of the graduation requirements in the course content setting, which embodies the goal of the SCM Course. The degree of ability required is based on the Bloom learning goal classification method. After the training of many knowledge points and professional skills, the expected learning effect is expressed by 1 (cognition), 2 (understanding), 3 (application), 4 (analysis), 5 (comprehensive) and 6 (judgment).

\section{2) The way to realize the goal}

In the main teaching link, we can find the teaching design, the way of teaching and the way to achieve the goal from the structure of the teaching link (such as table II). The details of the teaching link and the learning progress reflect the method and teaching strategy of realizing the goal. In teaching rules, we can see specifically which way to achieve a knowledge point in Table II in which we can find whether the teaching methods and teaching strategies adopted are teaching seminars, or problems guiding class exercises, or project guidance discussions.

TABLE I. THE RELATIONSHIP BETWEEN GRADUATION REQUIREMENTS AND THE DEGREE OF ABILITY REQUIRED

\begin{tabular}{|c|c|c|}
\hline Graduation requirements & $\begin{array}{l}\text { Weight } \\
\left(\sum=1\right)\end{array}$ & $\begin{array}{c}\text { Degree of ability } \\
\text { required }\end{array}$ \\
\hline 1. Engineering knowledge: to master the basic knowledge of measurement and control, such as SCM & 0.3 & L3 \\
\hline $\begin{array}{l}\text { 2. Problem analysis: to be able to identify, express and model through literature research for the complex } \\
\text { engineering problems and obtain effective conclusions. }\end{array}$ & 0.05 & $\mathrm{~L} 2$ \\
\hline $\begin{array}{l}\text { 3. The design / development solution: to be able to design solutions for complex engineering problems to meet } \\
\text { specific needs, simulated determine the feasibility and embody innovation awareness in the design process. }\end{array}$ & 0.1 & L3 \\
\hline $\begin{array}{l}\text { 4. Research: to be able to study complex engineering problems based on scientific principles and scientific } \\
\text { methods, including designing experiments, analyzing and interpreting data, and obtaining reasonable and } \\
\text { effective conclusions through information integration. }\end{array}$ & 0.25 & L3 \\
\hline $\begin{array}{l}\text { 5. Using modern tools: to be able to choose and use appropriate technology, resources, modern engineering tools } \\
\text { and information technology tools to analyze and solve complex engineering problems in the field of measurement } \\
\text { and control. }\end{array}$ & 0.1 & $\mathrm{~L} 4$ \\
\hline $\begin{array}{l}\text { 6. Team awareness: to be able to do a good job, communicate and cooperate with other team members in a } \\
\text { multidisciplinary team. }\end{array}$ & 0.05 & $\mathrm{~L} 2$ \\
\hline $\begin{array}{l}\text { 7. The expressive power: to be able to express ideas through oral, written, chart, engineering drawings, etc., and } \\
\text { effectively communicate with the industry colleagues and the public on complex engineering problems. }\end{array}$ & 0.1 & L5 \\
\hline $\begin{array}{l}\text { 8. Self-learning ability: to master the method of self-study, have the consciousness and ability of self- exploration } \\
\text { and study, and understand the way of expanding knowledge. }\end{array}$ & 0.05 & $\mathrm{~L} 2$ \\
\hline
\end{tabular}


TABLE II. THE STRUCTURE OF THE TEACHING LINK

\begin{tabular}{|c|c|c|c|c|c|c|c|c|c|c|c|}
\hline \multicolumn{2}{|c|}{$\begin{array}{l}\text { Theory Course } \\
\text { (school hours) }\end{array}$} & \multicolumn{2}{|c|}{$\begin{array}{c}\text { Experiment } \\
\text { (school hours) }\end{array}$} & \multicolumn{2}{|c|}{$\begin{array}{c}\text { Discussion } \\
\text { (school hours) }\end{array}$} & \multicolumn{2}{|c|}{$\begin{array}{c}\text { Project } \\
\text { (school hours) }\end{array}$} & \multicolumn{2}{|c|}{$\begin{array}{c}\text { Online learning } \\
\text { (school hours) }\end{array}$} & \multicolumn{2}{|c|}{$\begin{array}{c}\text { Exercises } \\
\text { (school hours) }\end{array}$} \\
\hline $\begin{array}{c}\text { In } \\
\text { class }\end{array}$ & $\begin{array}{c}\text { after } \\
\text { school }\end{array}$ & In class & after school & In class & $\begin{array}{c}\text { after } \\
\text { school }\end{array}$ & In class & $\begin{array}{c}\text { after } \\
\text { school }\end{array}$ & $\begin{array}{c}\text { after } \\
\text { school }\end{array}$ & In class & after school & In class \\
\hline 10 & 10 & 4 & 0 & 12 & 8 & 12 & 12 & 10 & 0 & 0 & 1 \\
\hline
\end{tabular}

C. Reform in teaching methods

\section{1) Changing the way of teaching in class}

Most of the traditional ways of education are inculcate, and teachers are the center. So that it is difficult to arouse the enthusiasm of the students, and the efficiency of the course is low. To improve the initiative of students' learning, the experiment of teaching methods is carried out in the course of SCM. Before class, the main contents to be learned in this course are arranged in the way of MOOC and fine class to students, and they are required to learn from themselves. In class, teachers elaborate on the key technologies and knowledge points to be mastered, and put forward questions in the form of projects, requiring students to discuss with group (3-4 persons) as the unit and submit answers. And then, the teachers organize discussions and make comments. This way of learning improves the students' interest in learning and the awareness of participation.

\section{2) Task driven practice teaching method}

The previous course content of experiment is divided into three types: confirmatory, design and comprehensive experiments. The teachers arrange the specific experimental contents before the class, and require the students to finish on time. Thus, students are always passive learning. In order to stimulate students' interest in learning and arouse students' learning enthusiasm, we introduced the learningoriented teaching method and the task driven teaching method centered on students' autonomous learning.

In the setting of the teaching content of the experiment course, first, the task is driven to make the students master the basic experimental skills in the completion of the basic tasks. Secondly, the study group as a unit, choose the project to guide students to design and build the application system based on MCU for real life. In the experimental class, teachers are responsible for guiding and answering questions. After class time, opening laboratory and applying for study hall provide the development environment for students, meanwhile the seminar and defense accept the results of the study. Through the implementation of the project, students find their own position in the team, understand learning autonomously, cooperating, communicating and expressing, at the same time, practicing skills, and cultivating innovation consciousness.
D. Reform and practice of assessment methods

The assessment of the course is the test of the effect of learning and the achievement of the graduation requirements. The corresponding assessment methods should be adopted at different stages and links in the assessment of learning outcomes, so as to build a curriculum assessment plan that combines process assessment and final assessment, theoretical examination and practical ability examination, as shown in Table III. The implementation of this program can help mobilize the enthusiasm of students' independent learning, enhance the ability of hands-on design and development, cultivate independent learning ability and innovative consciousness, and create the correct design thinking of SCM application system [3].

TABLE III. CURRICULUM ASSESSMENT STRUCTURE

\begin{tabular}{|c|c|}
\hline Spot check and normal operation & $20 \%$ \\
\hline Personal experimental ability & $20 \%$ \\
\hline Comprehensive project & $30 \%$ \\
\hline Final exam & $30 \%$ \\
\hline Total & $100 \%$ \\
\hline
\end{tabular}

As shown in Table 3, the assessment is divided into the teaching process assessment and the final examination, and the results are assigned to 7:3 respectively.

\section{1) Spot check and normal homework}

Spot checks accounts for 5\% of the total. It appears mainly in the form of classroom random tests. It may be a question, perhaps a 10-15 minute test, or a panel report submitted by a panel discussion to solve a problem. It can check the student classroom understanding of knowledge, but also on the process of teaching effect test. It is conducive to the dynamic adjustment of teaching content.

The normal homework refers to the three comprehensive exercises of this course, which requires a complete video recording of the design process. Its content includes design ideas and methods, specific content of hardware and software design, and displaying of operation effect. Homework accounts for $15 \%$ of the total. The results can reflect the students' learning results in the process of learning. 


\section{2) Personal experimental ability}

Experimental ability is tested by interview. When entering the door, the student draws an examination topic, one person one topic. And he should realize the function of the topic on the development board within 40 minutes, on the spot. It examines the students' individual understanding, ability to strain and the ability to discover problems and solve problems. The personal experimental ability accounts for $20 \%$ of the total.

\section{3) Comprehensive project}

According to the characteristics of single chip microcomputer control, students are divided into 13 project groups, with 13 different topics. The topic is determined by negotiation and cannot be repeated. Students can choose one according to their own ability, can add and subtract functions, and also can set up other projects by themselves. Teachers have different grades according to the differences of difficulty.

The method of assessment is symposium communication. Assessment scores include: the difficulty of the project, the degree of completion of the project, the elaboration of the project, the situation of the defense and the cooperation of the team, and the writing of the project. The assessment reflects the actual level of the requirements and requirements of graduation. The assessment accounts for $30 \%$ of the total.

\section{4) Final written examination}

Final written examination is open book examination. And it investigates the students' grasping and using of the main knowledge points, and examining the students' logic, summary ability, expressive ability and comprehensive analysis ability. The assessment accounts for $30 \%$ of the total.

\section{E. Improving the tracking and feedback mechanism to promote the sustainable development of the teaching quality of the course [4]}

To check and determine whether students meet the teaching quality requirement, and effectively, objectively and accurately evaluate the methods and measures of the evaluation of teaching quality, teaching tracking evaluation and feedback mechanism is established, on the basis of the sustainable development of engineering education accreditation and improvement mechanism. On one hand, current and previous students are asked for comments and suggestions on curriculum, teaching methods, teaching contents, classroom teaching, after school learning, practical teaching, teacher education and teaching resources, etc., through a symposium and a questionnaire survey. On the other hand, the whole understanding and judgment stems from the graduates and their employers on the quality of professional education. Through regular and effective tracking and evaluation of students, we can find problems and improve curriculum teaching timely, so as to achieve the goal of sustainable development of teaching quality.

\section{ACHIEVEMENTS OF REFORM}

Through a series of teaching reform and practice, students' learning ability, problem solving ability, practical ability, innovative ability and collaboration ability have been improved, at the same time, some teaching achievements have been achieved. In the past three years, 130 students in the field of measurement\& control technology and instrumentation have applied for and granted patents, and 43 papers have been published, in which 25 papers have been published in academic journals and international conferences. Moreover, 32 college students' innovative and entrepreneurial projects were approved, 33 students participated in the teachers' scientific research projects, and the students won 158 awards in major events at the national and provincial and ministerial level. With a solid foundation of professional knowledge, good innovation and professional quality, the graduates are welcomed by the employers, and the annual average employment rate is $90.15 \%$. Some outstanding graduates are studying for master's degree and doctorate degree. They have also won the approval by instructors in the field of scientific research and have achieved gratifying research results.

\section{CONCLUSION}

The professional accreditation of engineering education has put forward higher requirements for the course teaching. The curriculum content setting, the teaching mode and the examination mode reform should take into account all sorts of index points in graduation requirements of the curriculum. According to the requirements of graduation requirements, SCM course improves teaching mode by establishing a new syllabus, and constructs the corresponding course examination method which is combined with process assessment and final examination, theoretical examination and practice examination. The achievement of curriculum reform and the practice effect shows what met the requirements of the curriculum standards, but also realized the support of the curriculum to the graduation requirements of the measurement and control engineering talents. At the same time, it can better cultivate students' interest in learning, and fully mobilize the enthusiasm of learning, consequently, improve the effect of learning. As a result, it has the reference value.

\section{ACKNOWLEDGMENT}

This research was funded by the Project of Teaching Quality and Teaching Reform of Undergraduate Education in Tianjin Ordinary Higher Education Institutions (171006101C); and the Innovation and Entrepreneurship Training Reform Model Projects of Tianjin Agricultural University (20170413, 20170816). 


\section{REFERENCES}

[1] J. Lin, "Engineering education certification and engineering education reform and development," Higher engineering education research, 2015, vol. 2, pp.10-19.

[2] H. Mu, L. Xue, X. Niu, "The reform and practice of the syllabus of Engineering Drawing Course under the background of engineering education professional certification," Journal of Graphic Science, 2016, vol. 37, pp.711-717.

[3] R. Xie, Z. Ceng, C. Tian, "Based on the accreditation standard of engineering education, the research and practice of computer courses assessment program -- take the application of SCM system on the basis of C as an example", Education and Teaching Forum, 2017, vol. 48, pp. 146-148.

[4] W. Jin, L. Jiang, "Research on the teaching reform of SCM course under the background of engineering education professional certification", The study of curriculum education, 2017, vol. 46, pp. 221-222. 